\title{
Effect of Nitrogen on in Vitro Propagation of Endangered Medicinal Plant: Swertia Chirayita Roxb. Ex Flaming
}

\author{
Sandeep Kumar ${ }^{1 \mathbb{D}}$, Arvind Arya ${ }^{2 \mathbb{D}}$ \\ 1 Department of Biotechnology, Shobhit Institute of Engineering and Technology (Deemed-to-be-University), Meerut, Utter \\ Pradesh- 250010 India; dr.sandeepkumar@ shobhituniversity.ac.in (S.K.); \\ 2 Department of Biotechnology, Noida Institute of Engineering and Technology, Greater Noida. UP, India; \\ arvindarya@hotmail.com (A.A.); \\ * Correspondence: dr.sandeepkumar@shobhituniversity.ac.in (S.K.); arvindarya@hotmail.com (A.A.);
}

Scopus Author ID 57198297880

Received: 13.06.2021; Revised: 20.07.2021; Accepted: 25.07.2021; Published: 5.09.2021

\begin{abstract}
The effect of nitrogen was investigated on the organogenesis of Swertia chirayita (Gentianaceae) to overcome the challenges related to its cultivation. The best callogenic response was observed on root explants inoculated onto MS medium supplemented with BAP $(2.0 \mathrm{mg} / \mathrm{l})$ along with 2,4-D (0.5 mg/l) after 35 days of culture. Subsequent transfer of callus for multiplication on the same media composition under complete darkness presents the best results in terms of callus multiplication. Callogenic cultures were subculture onto modified MS medium supplemented with inorganic nitrogen sources, i.e., $\mathrm{NH}_{4} \mathrm{NO}_{3}$ (14-56N/l), $\mathrm{KNO}_{3}(100-400 \mathrm{~N} / \mathrm{l})$ with $\mathrm{BAP}(3.0 \mathrm{mg} / \mathrm{l})$ were observed. Organogenic response (52\%) was observed after 8-12 weeks of culturing. The maximum number of the shoot was recorded on MS medium with $\mathrm{NH}_{4} \mathrm{NO}_{3}(28 \mathrm{~N} / \mathrm{l}), \mathrm{KNO}_{3}(300 \mathrm{~N} / \mathrm{l})$ with BAP $(3.0 \mathrm{mg} / \mathrm{l})$. Moreover, $90 \%$ of them were able to regrow when sub-cultured on the same media. Sixteen weeks old multiple shoots were subcultured on MS medium supplemented with different auxins. IAA was proved to be the best hormone rooting purpose. However, the best rooting response regarding the number of roots and an average length of roots was obtained at IAA (1.0 mg/l). Survival of $90 \%$ was achieved when rooted plantlets were successfully established in substrate containing sand, vermicompost, and garden soil in equal proportion for hardening and acclimatized.
\end{abstract}

Keywords: Swertia chirayita; in vitro plant regeneration; root explants; organogenesis; plant growth regulators.

(C) 2021 by the authors. This article is an open-access article distributed under the terms and conditions of the Creative Commons Attribution (CC BY) license (https://creativecommons.org/licenses/by/4.0/).

\section{Introduction}

The use of traditional medicines in controlling and treating various diseases has gained a lot of popularity worldwide. Numerous traditional literature on medicinal plants' properties and use in various diseases is available in various cultures and parts of the world [1,2]. There is a growing awareness among people about the use of herbal medicines because they are safe and have no side effects [3]. Yet, the quest for the effectiveness and safety of these herbal medicines is in its infancy. Researchers are investigating the efficacy and safety of traditional plant-derived medications. Swertia chirayita is one such medicinal plant found in the Himalaya region at an altitude of 1200 to $2100 \mathrm{~m}$ from Kashmir to Bhutan and used to treat various human diseases [4]. It belongs to the family Gentianaceae and genus Swertia, which includes the annual and perennial herb. Swertia chirayita is one of the important medicinal plants among the other 40 other species of Swertia found in India. Continued harvest and overexploitation of 
this plant from the natural habitat have brought it to the brink of extinction [5]. The plant is already facing issues related to seed viability and germination. The premature harvest of the plant before the seed matures limits its natural regeneration. The vegetative propagation is also not supported, and hence an alternative method for propagation is soughed to save it from extinction. In vitro propagation of Swertia chirayita is very promising and beset with many limitations [4]. Only a few reports are available on micropropagation with nodal, shoot tip explant, and lab-grown seedlings [4,6-9]. Chaudhuri et al. [7,8] and Wang et al. [10] also reported the direct shoot regeneration from leaf explant. Wawrosch et al. and Kshirsagar et al. $[11,12]$ reported using root explants from the in vitro grown seedlings for shoot induction in vitro. Besides having some work done on in vitro propagation of Swertia chirayita there is still a dearth of an effective protocol for enhanced propagation of this plant. In the present research, the effect of nitrogen was optimized to develop a cost-effective in vitro regeneration protocol for Swertia chirayita.

\section{Materials and Methods}

\subsection{Plant materials.}

The mother plant grown in the Arboretum of G. B. Pant Institute of Himalayan Environment and Development, Sikkim Unit, Gangtok, was used to collect roots as explants. All the mother plants from which explants were collected were healthy and young. The root segments were first rinsed with tap water with tween 20 , then surface sterilized with $0.1 \%$ mercuric chloride $\left(\mathrm{HgCl}_{2}\right)$ for three minutes. Then, the explants were further washed with sterilized with double distilled water five times in laminar airflow to remove traces of $\mathrm{HgCl}_{2}$.

\subsection{Medium and culture conditions.}

After surface sterilization, the root explants were maintained at basal MS medium supplemented with different concentrations of 2,4-D (0.5 - $1.0 \mathrm{mg} / \mathrm{l})$ and BAP (0.5-5.0 $\mathrm{mg} / \mathrm{l}$ )alone as well as combinations. The callus cultures were kept in the dark while the shoot cultures were kept at $25 \pm 1^{\circ} \mathrm{C}$ for $16 \mathrm{hrs}$ in light and $8 \mathrm{hrs}$ in the dark.

\subsection{In vitro shoot induction.}

MS medium supplemented with $2 \%$ sucrose, solidified with $0.7 \%$ agar (w/v), and different concentrations of $\mathrm{NH}_{4} \mathrm{NO}_{3}(14-56 \mathrm{~N} / \mathrm{l})$ and $\mathrm{KNO}_{3}(100-400 \mathrm{~N} / \mathrm{l})$ with BAP $(3.0 \mathrm{mg} / \mathrm{l})$ was used for the induction of shoots from the callus cultures. As mentioned above, the cultures were incubated in light, and the data was recorded at regular intervals for four weeks.

\subsection{In vitro shoot multiplication}

After optimizing physicochemical conditions for the induction of shoots from callus culture, the shoots were transferred onto the fresh medium of similar composition for multiplication. Further, the optimization of medium and culture conditions was made to enhance the shoot multiplication. The effect of different concentrations of growth regulators viz. BAP $(0.5-5 \mathrm{mg} / \mathrm{l} \mathrm{BAP})$ and $\mathrm{Kn}(0.5$ to $3 \mathrm{mg} / \mathrm{l})$ alone and $\mathrm{BAP}(3,5 \mathrm{mg} / \mathrm{l})$ in combination with $\alpha$-NAA (1-2 mg/l) and IAA (0.5-5 mg/l) were used to optimize the results. 
2.5. Rooting of in vitro raised shoot.

In vitro shoots were transferred to the rooting medium. The basal MS medium in combination with different auxins viz. $\alpha$-NAA, IAA and IBA was used in the liquid and semisolid form. The different concentrations of auxins were tested to optimize the rooting response of in vitro raised shoots. The data was recorded after 4 and 8 weeks of culturing. The number of roots and the average length of the roots were recorded.

\subsection{Hardening and acclimatization.}

Macronutrients of MS medium (without growth regulators and carbon sources) were used. The plants were kept in the jam bottle containing a sterilized hardening medium.

\subsection{Statistical analysis.}

Experiments were conducted in a randomized block design (RBD), and in 10 replicates.

\section{Results and Discussion}

\subsection{Initiation of callus culture:}

The in vitro callus cultures were produced from root explants cultured on MS medium supplemented with different plant growth regulators viz concentrations. BAP (0.5-5 mg/l) and 2,4-D (0.5 - $1.0 \mathrm{mg} / \mathrm{l})$ in combinations (Graph 1). The combinations of auxins and cytokinin are reported to enhance the induction of callus from root explants in many other dicot species [13]. In order to make the protocol reproducible and cost-effective fewer numbers and concentrations of the hormones were used. However, the callus induction was also reported on $1 / 2 \mathrm{X}$ MS medium containing BA, Kn $(2.22-4.44 \mu \mathrm{M}), \alpha$-NAA $(2.69-5.37 \mu \mathrm{M})$, and $2.26 \mu \mathrm{M}$ 2,4-D by Chaudhuri et al. [14]. Kumar et al. [15] reported the callusing from leaf explants of Swertia chirayita upon culturing on $15.0 \mu \mathrm{M}$ 2,4-D within 60 days. Studies made by other researchers were referred to make a reach to the final optimal concentration of both the hormones for callus induction [16-18]. The best results were obtained on $2.0 \mathrm{mg} / \mathrm{l} \mathrm{BAP}$ in combination with $0.5 \mathrm{mg} / \mathrm{l} 2,4-\mathrm{D}$. The maximum amount of the callus (1090 $\mathrm{mg}$ ) was obtained at the optimal concentration and further subjected to the callus multiplication (Graph 2, Figure 1). The multiplied callus cultures were transferred on a cytokinin medium for subsequent organogenesis from callus culture. Balaraju et al. [19] has also reported the somatic embryogenesis from leaves and root explants of in vitro grown young seedlings of Swertia chirata. He reported that the 2,4-D (1.0 or $1.5 \mathrm{mg} \mathrm{L}-1)$ alone was good for the initiation of embryogenic tissue

\subsection{In vitro shoot induction.}

The callus cultures were transferred on to MS medium supplemented with 3\% sucrose, $0.7 \%$ agar (w/v) and different concentrations of $\mathrm{NH}_{4} \mathrm{NO}_{3}(14-56 \mathrm{~N} / \mathrm{l})$ and $\mathrm{KNO}_{3}(100-400 \mathrm{~N} / \mathrm{l})$ with BAP (3.0 mg/l) (Graph 3, Graph 4). Induction of shoots from the callus cultures was observed in four weeks of culturing. The maximum number of shoots $(52 \%)$ were obtained on medium with $\mathrm{NH}_{4} \mathrm{NO}_{3}(28 \mathrm{~N} / \mathrm{l}), \mathrm{KNO}_{3}(300 \mathrm{~N} / \mathrm{l})$, and BAP $(3.0 \mathrm{mg} / \mathrm{l})$. Further, the maximum number of shoots (32 shoots per callus) and length $(3.6 \mathrm{~cm}$ mean length) were also found on 
the same medium (Graph 5). The elongation of shoots was also reported on MS medium with $\mathrm{GA}_{3}(0.1 \mathrm{mg} / \mathrm{l})$ [20]. Kumar et al. [15] reported the shoot organogenesis from callus culture on MS medium supplemented with BAP $(10.0 \mu \mathrm{M})$ with $\mathrm{GA}_{3}(5.0 \mu \mathrm{M})$. They also reported that BAP $(5.0 \mu \mathrm{M})$ was also good for the induction of shoots from the callus cultures. There was a marked difference in the morphology of shoots reported when cultured on BAP alone and in BAP and $\mathrm{GA}_{3}$ containing medium. Wawrosch et al. [11] reported the adventitious shoot regeneration in Swertia chirata upon culturing on $3 \mu \mathrm{M}$ 6-benzylaminopurine (BAP) within 3 weeks of culturing. In another study, the shoot induction was reported on 1/2x MS medium supplemented with $0.44 \mu \mathrm{M}$ 6-benzylaminopurine and $4.65 \mu \mathrm{M}$ 6-furfurylaminopurine [8]. In this study, it is also found that the MS medium supplemented with $10 \mathrm{mM} \mathrm{KNO}_{3}$ and $75 \mathrm{mg}$ $1^{-1}$ of casein hydrolysate produced a maximum number of shoots. In one study, the shoot tip explants from the in vitro grown seedlings were used to induce multiple shoots from the explants. The shoot tip explants were reported to give a maximum response on MS medium with BAP at $1.0 \mathrm{mg} / \mathrm{l}$ and $\mathrm{KN}, 0.1 \mathrm{mg} / \mathrm{l}$ [20].

\subsection{In vitro shoot multiplication.}

The shoots obtain from callus culture were transferred to a fresh medium with different concentrations of cytokinin and auxins (Graph 6). BAP alone $(2 \mathrm{mg} / \mathrm{l})$ and in combination with $\mathrm{Kn}(1,3 \mathrm{mg} / \mathrm{l})$ provided the best result (Figure 2). Around $90 \%$ of the shoots were found successfully cultured and proliferated upon sub-culture on the same media. The addition of reduced nitrogen in the medium is reported to increase the length of shoots and the number of leaves in potato cultivars [21,22]. Ammonium nitrate concentrations 3.4-10 mM and 3.4-15 $\mathrm{mM}$ were also reported to develop somatic embryos in black spruce and red spruce, respectively [23]. Nitrogen plays a crucial role in plant growth and differentiation. Both its amount and form have a significant effect on cell growth and differentiation. However, MS medium has a high inorganic nitrogen concentration $(60 \mathrm{mM})$, supporting most plant species. Still, the standardization of the appropriate ratio of nitrate to ammonium is essential for optimal plant growth [24,25]. In the present investigation, the addition of ammonium nitrate and potassium nitrate was also found beneficial for the induction as well as multiplication of shoots.

\subsection{Rooting of in vitro raised shoots.}

For the rooting response, multiplied shoots were transferred on MS medium with different concentrations of auxins (NAA, IAA, and IBA). Different concentrations of NAA (0.1-2.0 mg/l) was found non-significant for root induction. IBA at different concentrations (0.1-2.0 $\mathrm{mg} / \mathrm{l})$ gave the rooting response, but the maximum rooting was found on medium supplemented with IAA (1.0 mg/l) (Graph 7, Figure 2). Balaraju et al. [20] reported the rooting of in vitro raised shoots of Swertia chirayita on MS medium containing $\alpha-\mathrm{NAA}, 0.1 \mathrm{mg} / \mathrm{l}$ within four weeks of culturing. In another report, the MS medium supplemented with IBA $(5.0 \mu \mathrm{M})$ was reported to produce 50 roots per microshoot [15]in 45 days of culture. Kshirsagar et al. [12] reported the best rooting of in vitro raised shoots of another species (Swertia lawii Burkill) on $1 / 2 \mathrm{MS}$ medium containing IAA $\left(3.0 \mathrm{mg}^{-1}\right)$. In a similar report on in vitro propagation of Swertia chirayita, $1 / 2 \mathrm{MS}$ strength supplemented with $400 \mathrm{mg} / \mathrm{L}$ activated charcoal (AC) and $0.1 \mathrm{mg} / \mathrm{L} \alpha$-NAA showed $80.30 \%$ root induction from in vitro grown shoots [26]. 


\subsection{Hardening and acclimatization.}

The rooted shoots were transferred on a hardening medium containing sand, vermicompost, and garden soil in equal proportion for hardening, and acclimatized $90 \%$ of the transferred plants were successfully established in the substrate (Figure 3). The hardening of well-rooted plants of Swertia chirayita was reported on the mixture of soil, sand, and FYM (2:1:1) under partial shade (75\% agro shade net) [15]. An average $94 \%$ success rate was reported in the in vitro hardening of Swertia chirayita in the growth room and by ex vitro hardening in greenhouse conditions[19,27].

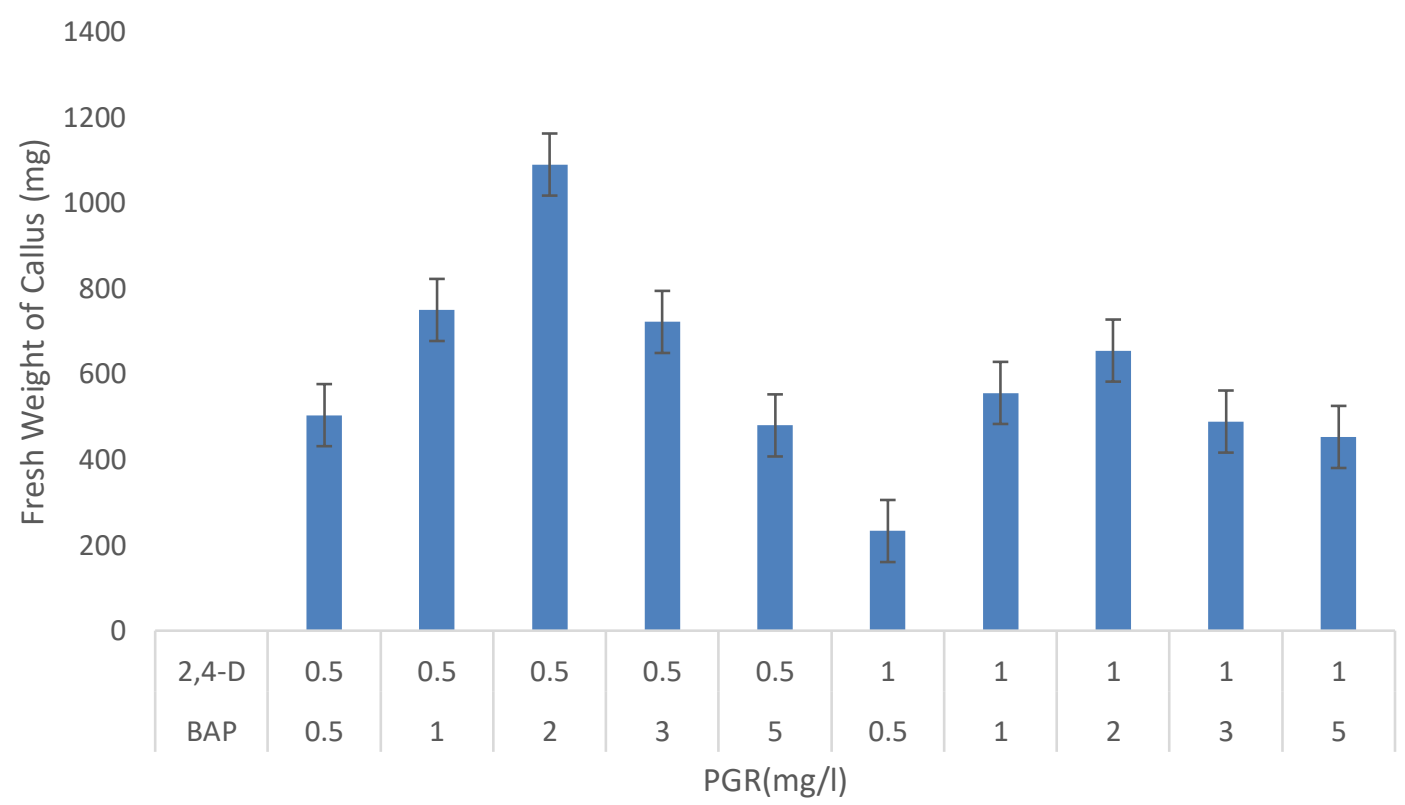

Graph 1. Effect of BAP and 2,4-D on callogenesis (fresh weight is measured in mg).

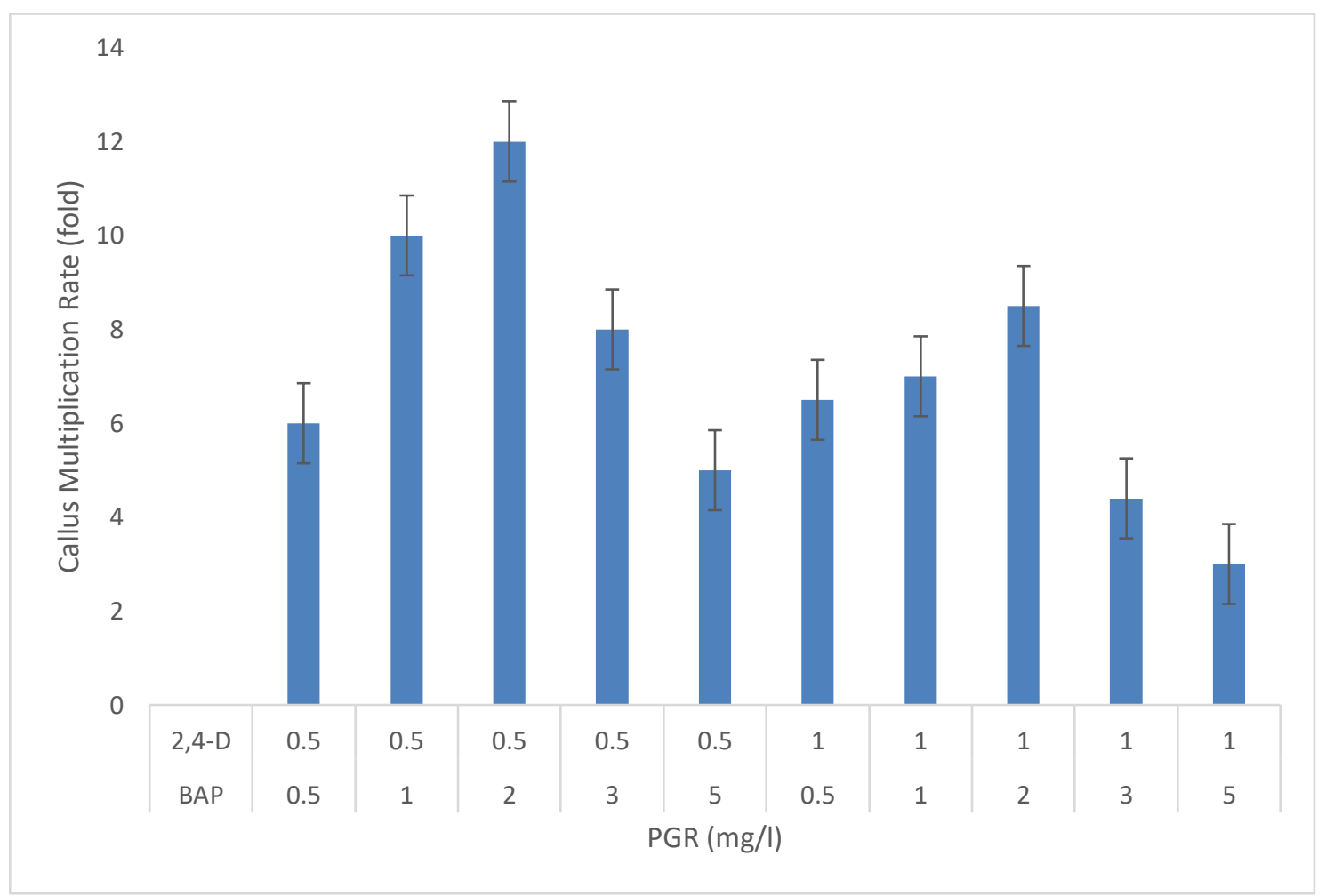

Graph 2. Effect of BAP and 2,4-D on callogenesis (Callus multiplication rate is measured in folds). 


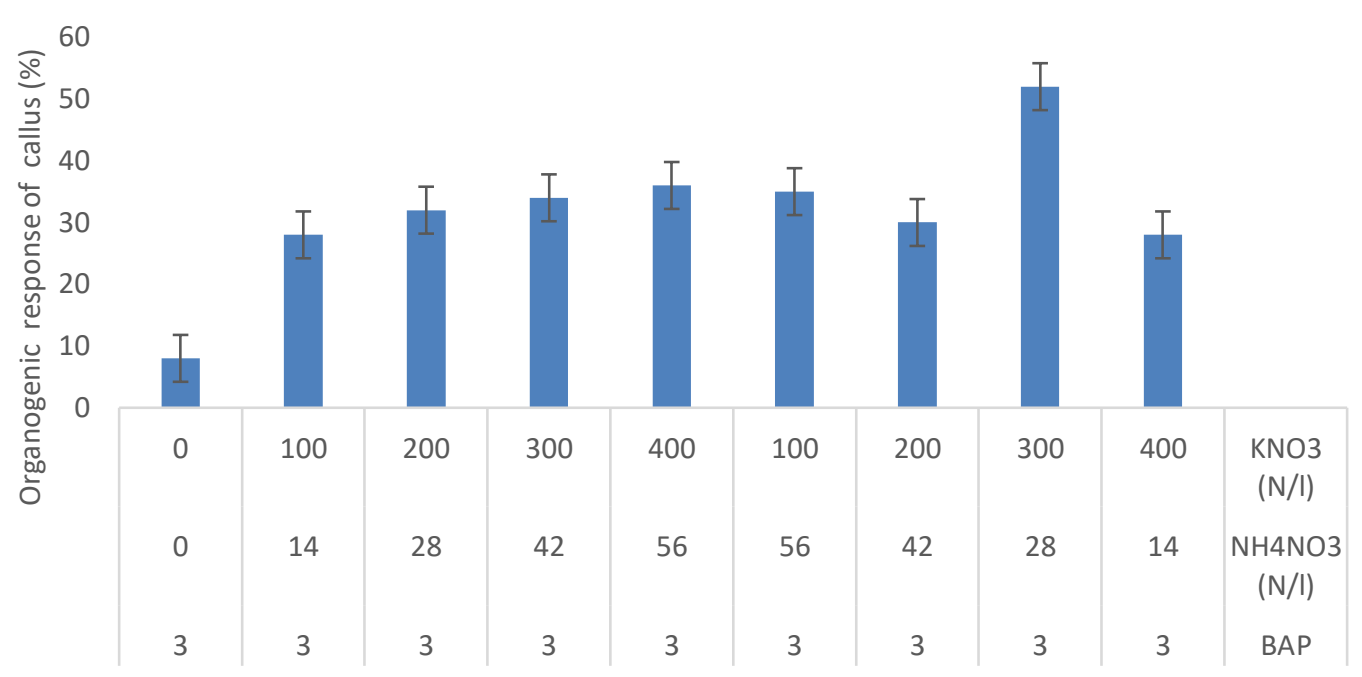

Graph 3. Effect of different concentrations of $\mathrm{NH}_{4} \mathrm{NO}_{3}$ and $\mathrm{KNO}_{3}$ on organogenesis of callus cultures.

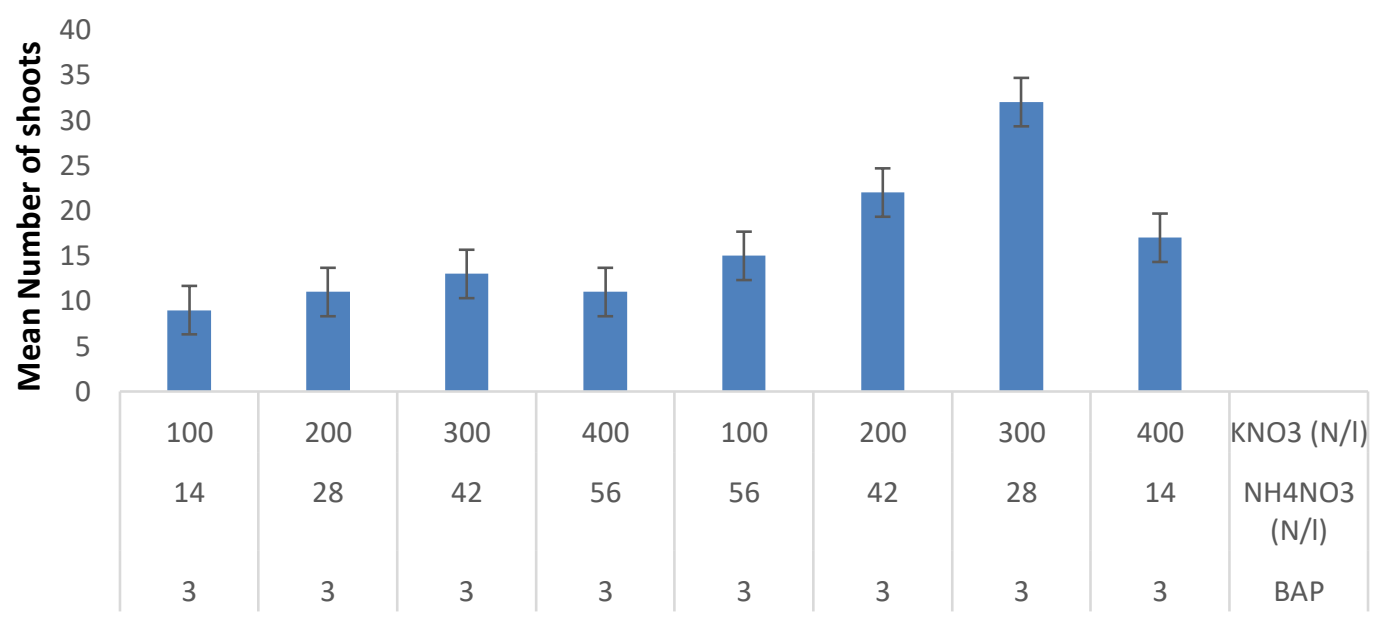

Graph 4. Effect of different concentrations of $\mathrm{NH}_{4} \mathrm{NO}_{3}$ and $\mathrm{KNO}_{3}$ on the mean number of shoots per callus clump.

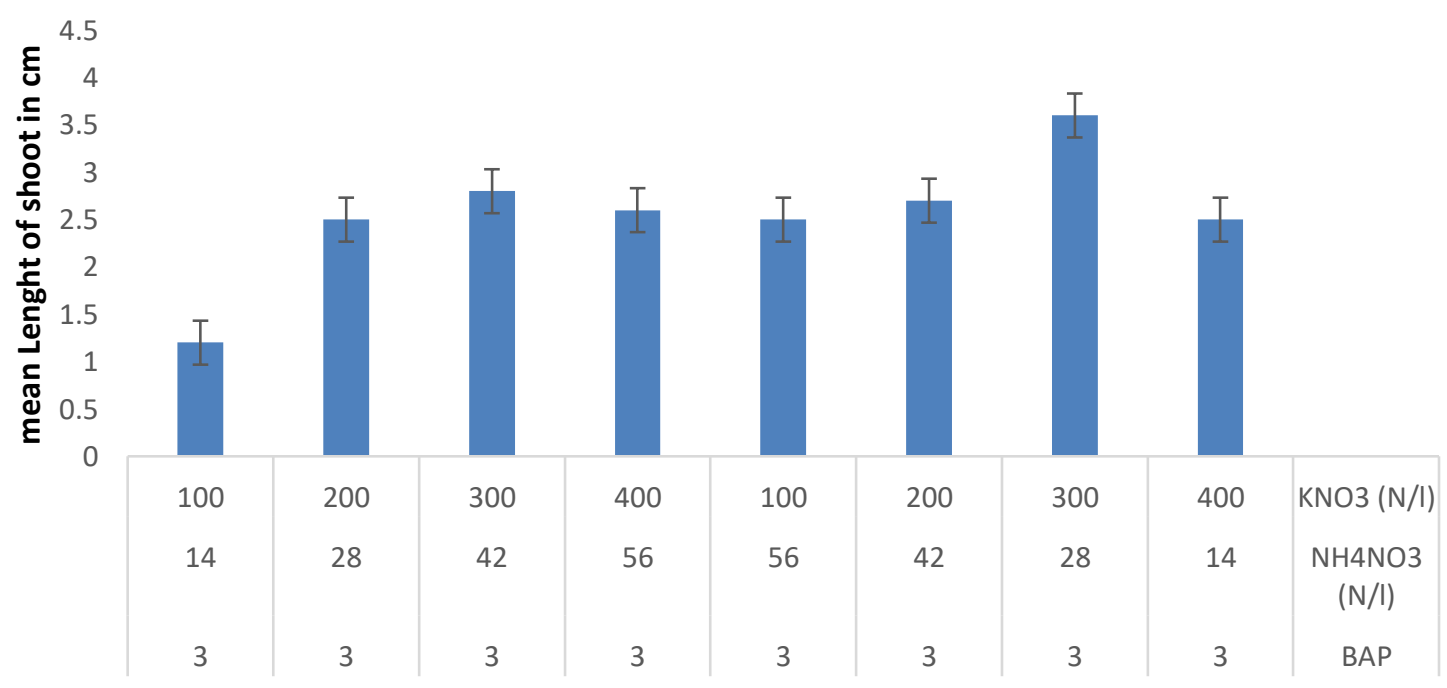

Graph 5. Effect of different concentrations of $\mathrm{NH}_{4} \mathrm{NO}_{3}$ and $\mathrm{KNO}_{3}$ on mean length of shoots. 


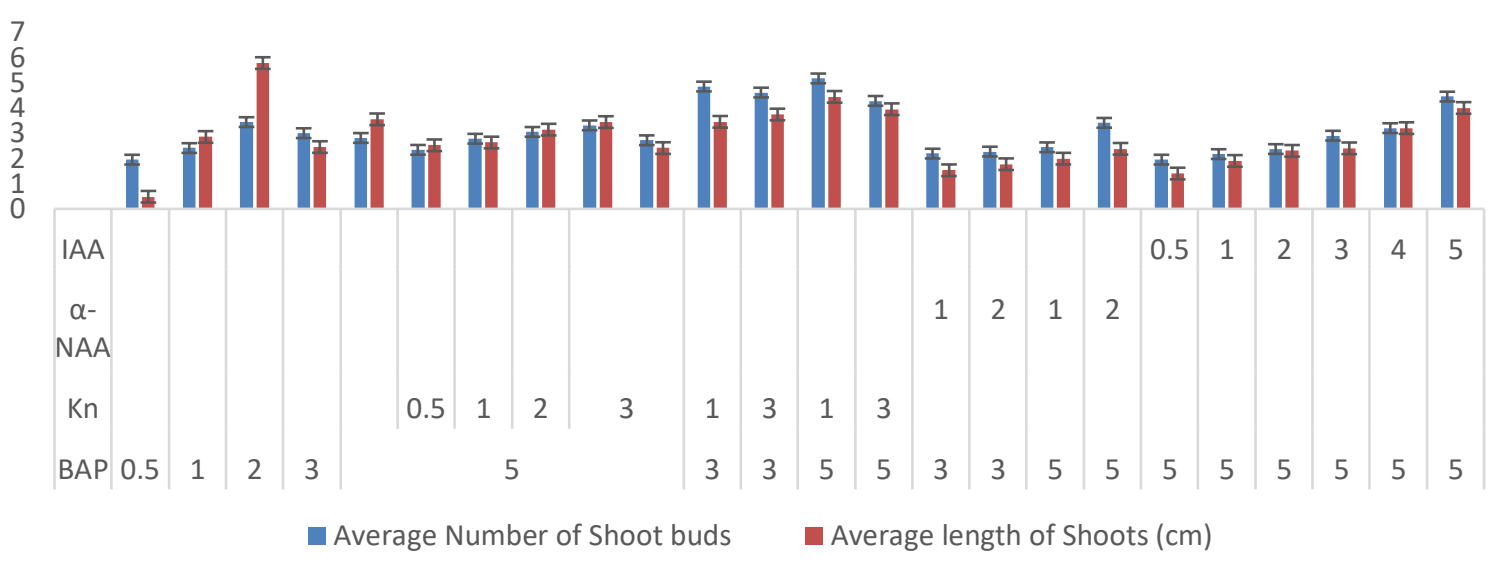

Graph 6. Effect of PGRs on shoot multiplication.

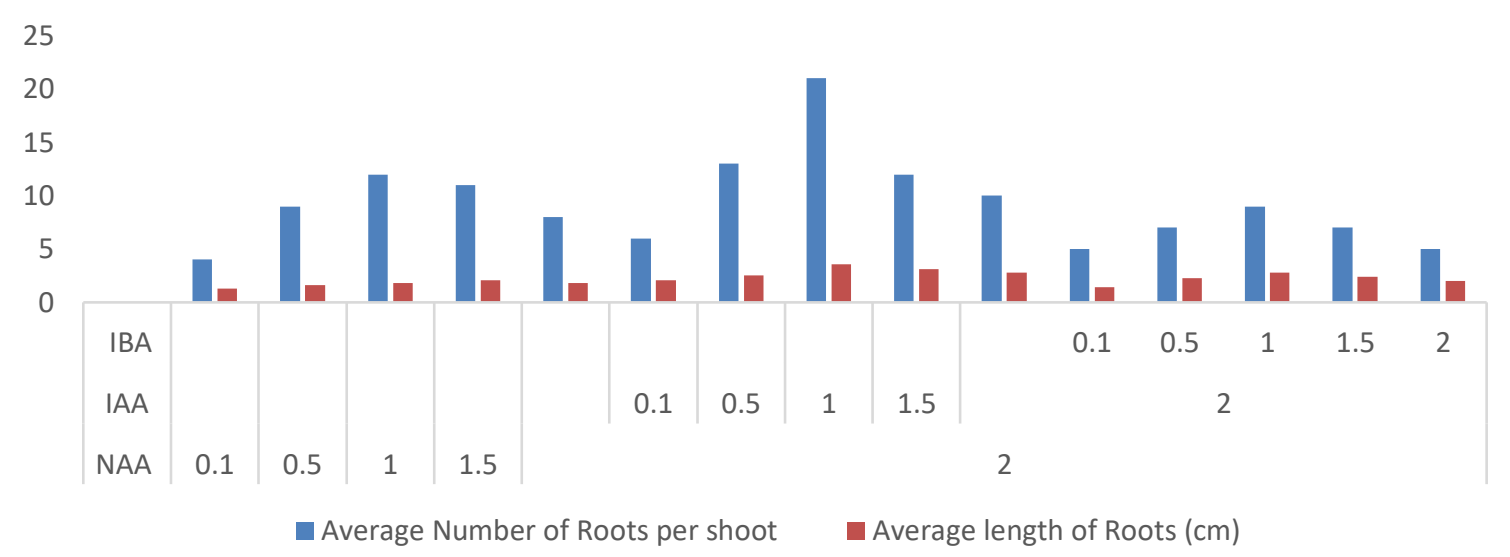

Graph 7. Effect of Auxins on rooting of in vitro shoots.
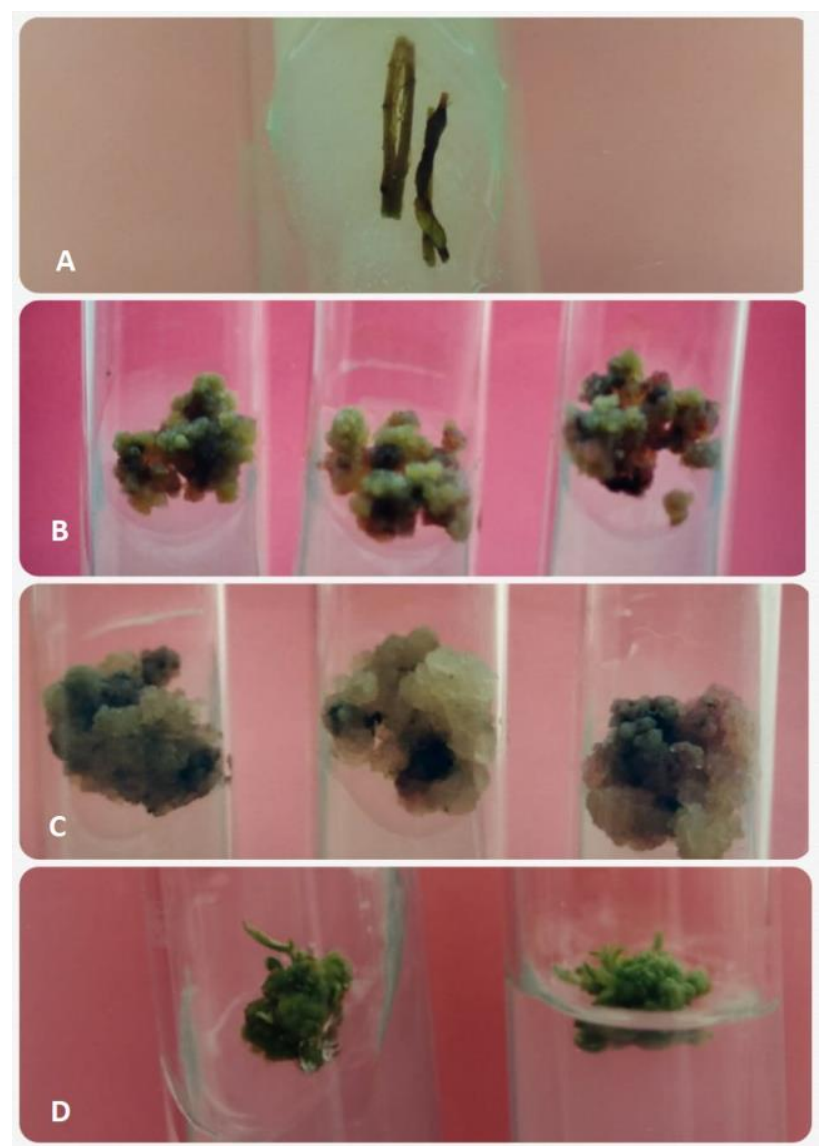

Figure 1. Initiation multiplication and organogenesis in callus culture from root explant of Swertia chirayita. 


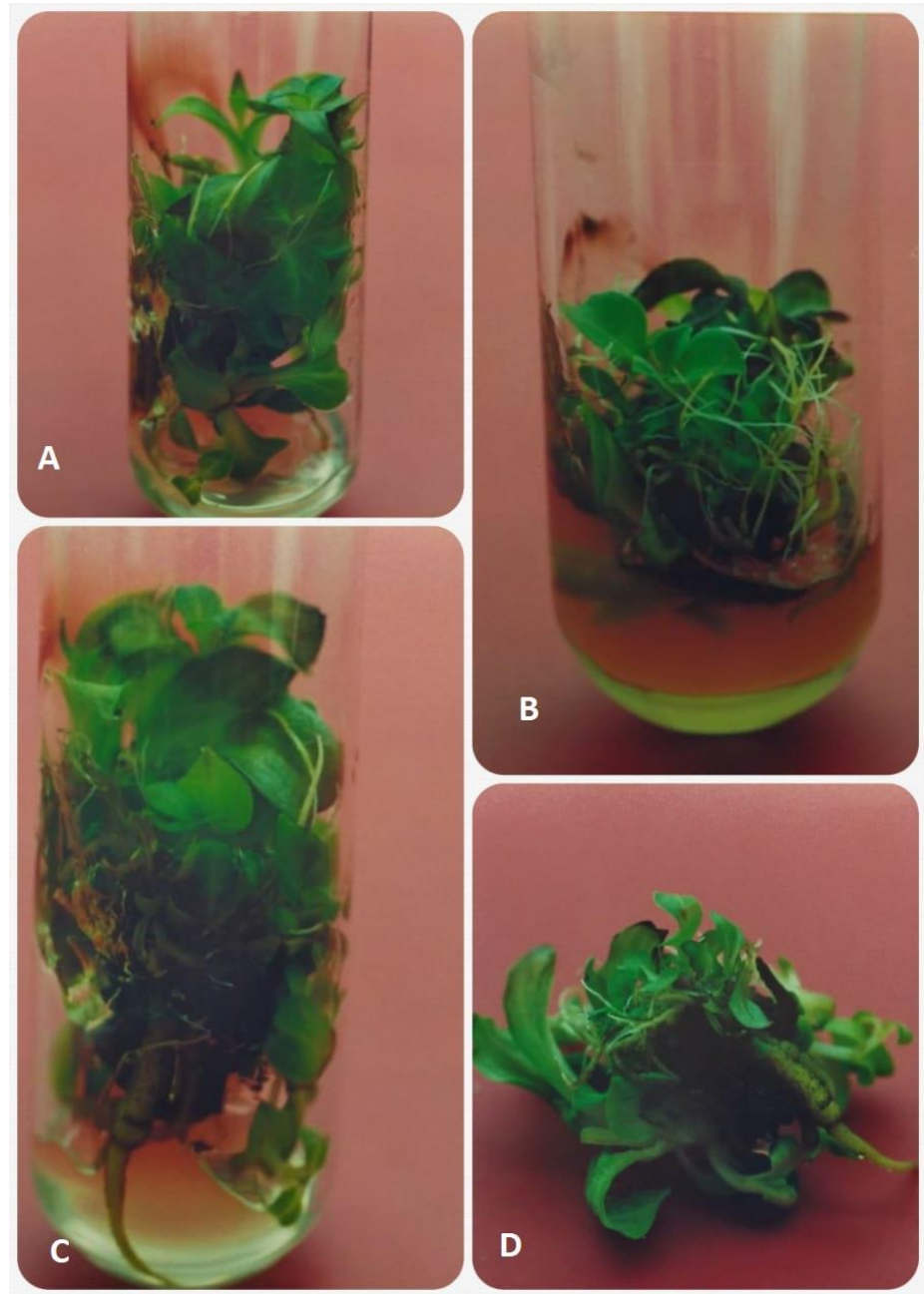

Figure 2. Multiplication and rooting of in vitro raised shoot of Swertia chirayita.

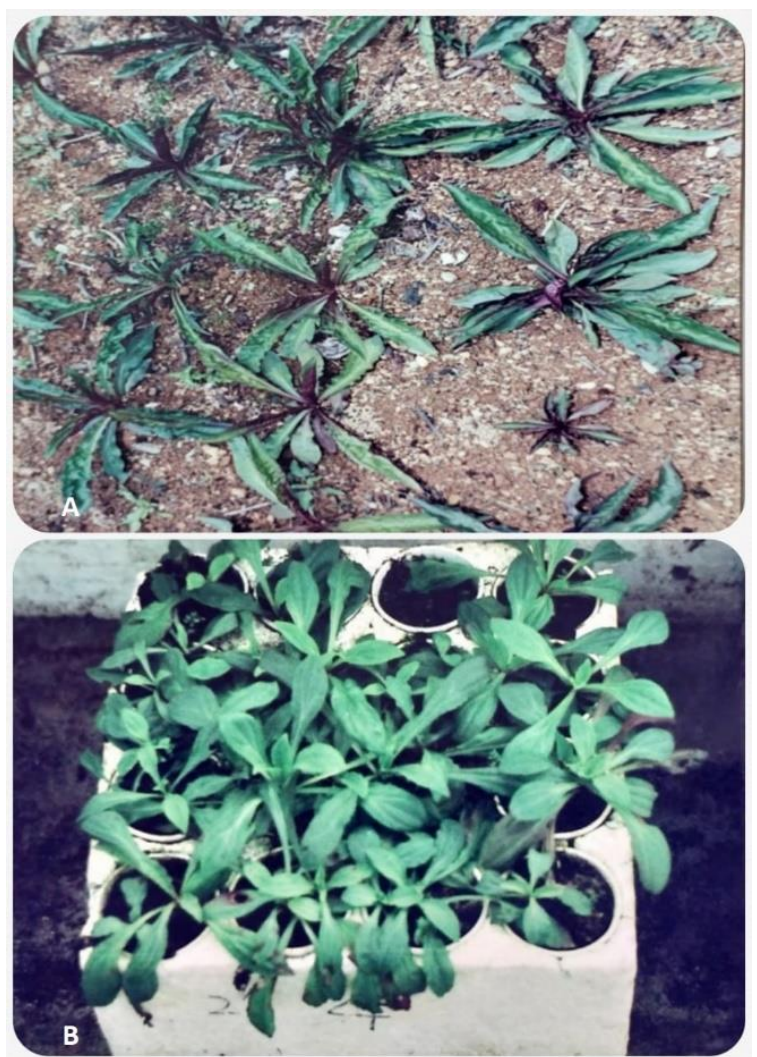

Figure 3. Hardening of in vitro rooted plantlets of Swertia chirayita. 


\section{Conclusions}

This study indicates the varied responses to the different forms of inorganic nitrogen provided, representing the previously reported importance of this nutrient in determining plant morphology and morphogenesis in vitro.

\section{Funding}

This research received no external funding.

\section{Acknowledgments}

The authors thank G. B. Pant Institute of Himalayan Environment and Development, Sikkim Unit, Gangtok, for providing access to plant material and necessary support to carry out the experiments.

\section{Conflicts of Interest}

The authors declare no conflict of interest.

\section{References}

1. Dafni, A.; Böck, B. Medicinal plants of the Bible - revisited. J. Ethnobiol. Ethnomed. 2019, 15, https://doi.org/10.1186/s13002-019-0338-8.

2. Caballero-Serrano, V.; McLaren, B.; Carrasco, J.C.; Alday, J.G.; Fiallos, L.; Amigo, J.; Onaindia, M. Traditional ecological knowledge and medicinal plant diversity in Ecuadorian Amazon home gardens. Glob. Ecol. Conserv. 2019, 17, e00524, https://doi.org/10.1016/j.gecco.2019.e00524.

3. Batiha, G.E.S.; Beshbishy, A.M.; El-Mleeh, A.; Abdel-Daim, M.M.; Devkota, H.P. Traditional uses, bioactive chemical constituents, and pharmacological and toxicological activities of Glycyrrhiza glabra L. (fabaceae). Biomolecules 2020, 10, https://doi.org/10.3390/biom10030352.

4. Kumar, V.; Van Staden, J. A review of Swertia chirayita (Gentianaceae) as a traditional medicinal plant. Front. Pharmacol. 2016, 6, 308, https://doi.org/10.3389/fphar.2015.00308.

5. Pradhan, B.K.; Badola, H.K. Swertia chirayta, a threatened high-value medicinal herb: Microhabitats and conservation challenges in Sikkim Himalaya, India. Mt. Res. Dev. 2015, 35, 374-381, https://doi.org/10.1659/MRD-JOURNAL-D-14-00034.1.

6. Sharma, V.; Kamal, B.; Srivastava, N.; Negi, Y.; Dobriyal, A.K.; Jadon, V.S. Enhancement of in vitro growth of Swertia chirayita Roxb. Ex Fleming co-cultured with plant growth promoting rhizobacteria. Plant Cell. Tissue Organ Cult. 2015, 121, 215-225, https://doi.org/10.1007/s11240-014-0696-9.

7. Chaudhuri, R.K.; Pal, A.; Jha, T.B. Conservation of Swertia chirata through direct shoot multiplication from leaf explants. Plant Biotechnol. Rep. 2008, 2, 213-218, https://doi.org/10.1007/s11816-008-0064-5.

8. Chaudhuri, R.K.; Pal, A.; Jha, T.B. Production of genetically uniform plants from nodal explants of Swertia chirata Buch.-Ham. ex Wall. - An endangered medicinal herb. Vitr. Cell. Dev. Biol. - Plant 2007, 43, 467472, https://doi.org/10.1007/s11627-007-9095-9.

9. Kumar, V.; Chandra, S. High frequency somatic embryogenesis and synthetic seed production of the endangered species Swertia chirayita. Biol. 2014, 69, 186-192, https://doi.org/10.2478/s11756-013-0305-0.

10. Wang, L.; An, L.; Hu, Y.; Wei, L.; Li, Y. Influence of phytohormones and medium on the shoot regeneration from leaf of Swertia chirata Buch.-Ham. Ex wall. in vitro. African J. Biotechnol. 2009, 8, 2513-2517, https://doi.org/10.5897/AJB09.452.

11. Wawrosch, C.; Maskay, N.; Kopp, B. Micropropagation of the threatened Nepalese medicinal plant Swertia chirata Buch.-Ham. ex Wall. Plant Cell Rep. 1999, 18, 997-1001, https://doi.org/10.1007/s002990050697.

12. Kshirsagar, P.R.; Mohite, A.; Suryawanshi, S.; Chavan, J.J.; Gaikwad, N.B.; Bapat, V.A. Plant regeneration through direct and indirect organogenesis, phyto-molecular profiles, antioxidant properties and swertiamarin production in elicitated cell suspension cultures of Swertia minor (Griseb.) Knobl. Plant Cell. Tissue Organ Cult. 2020, 144, 383-396, https://doi.org/10.1007/s11240-020-01962-8. 
13. Saeed, W.; Naseem, S.; Gohar, D.; Ali, Z. Efficient and reproducible somatic embryogenesis and micropropagation in tomato via novel structures - Rhizoid Tubers. PLoS One 2019, 14, https://doi.org/10.1371/journal.pone.0215929.

14. Chaudhuri, R.K.; Pal, A.; Jha, T.B. Regeneration and characterization of Swertia chirata Buch.-Ham. ex Wall. plants from immature seed cultures. Sci. Hortic. (Amsterdam). 2009, 120, 107-114, https://doi.org/10.1016/j.scienta.2008.09.022.

15. Kumar, R.R.; Purohit, V.K.; Prasad, P.; Nautiyal, A.R. Efficient In Vitro Propagation Protocol of Swertia chirayita (Roxb. ex Fleming) Karsten: A Critically Endangered Medicinal Plant. Natl. Acad. Sci. Lett. 2018, 41, 123-127, https://doi.org/10.1007/s40009-018-0624-3.

16. Rajan, M.; Soororbhavan, S.; Chandran, V.; Mathew, L. Callus induction, indirect organogenesis and plantlet regeneration from different explants of vernonia anthelmintica (L.) willd. J. Appl. Biol. Biotechnol. 2020, 8, 17-22, https://doi.org/10.7324/JABB.2020.80304.

17. Sultana, K.W.; Chandra, I.; Roy, A. Callus induction and indirect regeneration of Thunbergia coccinea Wall. Plant Physiol. Reports 2020, 25, 58-64, https://doi.org/10.1007/s40502-020-00501-z.

18. Singh, V.; Jaryan, V.; Sharma, V.; Sharma, H.; Sharma, I.; Sharma, V. Swertia chirayita. Himal. Med. Plants 2021, 2021, 223-242, https://doi.org/10.1016/b978-0-12-823151-7.00016-7.

19. Balaraju, K.; Saravanan, S.; Agastian, P.; Ignacimuthu, S. A rapid system for micropropagation of Swertia chirata Buch-Ham. ex Wall.: An endangered medicinal herb via direct somatic embryogenesis. Acta Physiol. Plant. 2011, 33, 1123-1133, https://doi.org/10.1007/s11738-010-0640-5.

20. Balaraju, K.; Agastian, P.; Ignacimuthu, S. Micropropagation of Swertia chirata Buch.-Hams. ex Wall.: A critically endangered medicinal herb. Acta Physiol. Plant. 2009, 31, 487-494, https://doi.org/10.1007/s11738-008-0257-0.

21. Zarrabeitia, A.; Lejarcegui, X.; Veramendi, J.; Mingo-Castel, A.M. Influence of nitrogen supply on micropropagation and subsequent microtuberization of four potato cultivars. Am. Potato J. 1997, 74, 369378, https://doi.org/10.1007/BF02852776.

22. Avila, A. de L.; Pereyra, S.M.; Collino, D.J.; Argüello, J.A. Effect of nitrogen source on growth and morphogenesis of three micropropagated potato cultivars. Potato Res. 1994, 37, 161-168, https://doi.org/10.1007/BF02358717.

23. Tremblay, L.; Tremblay, F.M. Effects of gelling agents, ammonium nitrate, and light on the development of Picea mariana (Mill) B.S.P. (black spruce) and Picea rubens Sarg. (red spruce) somatic embryos. Plant Sci. 1991, 77, 233-242, https://doi.org/10.1016/0168-9452(91)90092-M.

24. George, E.F.; Hall, M.A.; Klerk, G.J. De The Components of plant tissue culture media I: Macro- and micronutrients. In Plant Propagation by Tissue Culture 3rd Edition; The Netherlands Springer 2008, 1, 65-113, https://www.researchgate.net/publication/226836015_The_Components_of_Plant_Tissue_Culture_Media_I _Macro-_and_Micro-Nutrients.

25. Zhang, K.; Wu, Y.; Hang, H. Differential contributions of NO3-/NH4+ to nitrogen use in response to a variable inorganic nitrogen supply in plantlets of two Brassicaceae species in vitro. Plant Methods 2019, 15, 86, https://doi.org/10.1186/s13007-019-0473-1.

26. Shailja; Kanwar, K.; Soni, M.; Singh, A. In vitro propagation and conservation of an endangered high value medicinal herb Swertia chirayita of temperate Himalayas. Indian J. Plant Physiol. 2017, 22, 247-257, https://doi.org/10.1007/s40502-017-0294-z.

27. Joshi, P.; Dhawan, V. Axillary multiplication of Swertia chirayita (Roxb. Ex Fleming) H. Karst., a critically endangered medicinal herb of temperate Himalayas. Vitr. Cell. Dev. Biol. - Plant 2007, 43, 631-638, https://doi.org/10.1007/s11627-007-9065-2. 